\title{
RESPON IBU PKK DESA MADU SARI KABUPATEN KUBU RAYA TERHADAP PELATIHAN PENGOLAHAN PANGAN LOKAL BERBAHAN BAKU NANAS (Ananas Comosus L)
}

\author{
Yokhebed \\ Pendidikan Biologi, Fakultas Keguruan dan Ilmu Pendidikan, Universitas Tanjungpura, \\ Jalan Prof. Dr. Hadari Nawawi, Pontianak, Kalimantan Barat, Indonesia \\ e-mail: yokhebed@fkip.untan.ac.id
}

\begin{abstract}
Abstrak
Produksi nanas kabupaten Kuburaya menempati posisi tertinggi dibandingkan buah lainnya, sehingga diperlukan upaya pengolahan menjadi produk olahan yang beragam yang memilki nilai ekonomi dan meningkatkan daya simpan. Kegiatan PKM ini bertujuan memberikan pengetahuan dan keterampilan kepada ibu penggerak kesejahteraan keluarga (PKK) di desa Madu sari Kabupaten Kuburaya terhadap pembuatan produk olahan pangan berbahan baku nanas. Kegiatan dilakukan dengan pelatihan dan pendampingan. Setelah kegiatan pelatihan diberikan angket kepada 25 orang ibu PKK. Berdasarkan hasil analisis data diperoleh respon terhadap pelatihan dengan kategori sangat tinggi sebesar 64\%, sedangkan kategori tinggi sebesar $36 \%$. Ketertarikan ibu ibu PKK dalam mengikuti pelatihan sebesar 91\%, sedangkan pelatihan menambah wawasan ibu ibu PKK sebesar 86\%. Dengan demikian dapat disimpulkan pelatihan pengolahan pangan lokal berbahan baku nanas memperoleh respon positif dari ibu PKK desa Madu Sari Kabupaten Kuburaya.
\end{abstract}

Kata Kunci: Respon, pelatihan, pangan lokal, nanas.

\begin{abstract}
Pineapple production in Kuburaya district occupies the highest position compared to other fruits, so it is necessary to process processing into a variety of processed products that have economic value and increase shelf life. This study aims to determine the response of the mother of the family welfare activist (PKK) in the village of Madu sari, Kuburaya Regency to the training of making processed foods made from pineapple raw materials. This research is in the form of descriptive, using a data collection tool in the form of a questionnaire given to 25 PKK mothers. Based on the results of data analysis, the response rate is very high by 64\%, while the high category is 36\%. The interest of PKK women in attending training was $91 \%$, while the training increased the insight of PKK mothers by $86 \%$. Thus it can be concluded that local food processing training made from pineapple raw received a positive response from the mother PKK Madu Sari village, Kuburaya Regency.
\end{abstract}

Keywords: content, formatting, article.

\section{PENDAHULUAN}

Buah nanas di Kalimantan Barat keberadaannya sangat melimpah. Berdasarkan data Badan Pusat Statistik provinsi Kalimantan Barat produksi buahbuahan menurut Kabupaten/Kota tahun 2017 nanas berada pada urutan ketiga setelah buah jeruk dan pisang. Salah satu daerah yang banyak memproduksi buah nanas di Kalimantan Barat adalah kabupaten kuburaya. Salah satu dari 8 
kecamatan di Kabupaten Kuburaya yang paling tinggi memproduksi nanas yaitu Kecamatan sungai raya yaitu sebanyak 52.024,80 (BPS Kuburaya, 2017). Pada tahun 2017 juga total produksi nanas kabupaten Kuburaya menempati posisi tertinggi dibandingkan buah lainnya yaitu dengan total dengan jumlah produksi sebesar 55.196,90 ton, pisang sebesar 15.711,10 ton, nangka/ cempedak sebesar 2.662,20 ton, dan rambutan sebesar 1.439,00 ton (BPS kalbar, 2017).

Nanas adalah salah satu jenis tanaman yang banyak digemari orang karena rasanya enak, segar, dan sedikit asam. Secara umum nanas memiliki kandungan gizi dan vitamin, diantaranya kalori, protein, lemak, karbohidrat, kalsium, vitamin A, vitamin C, dan sedikit vitamin B (Prahasta, 2009). Buah nanas sangat banyak manfaatnya bagi kesehatan dalam 100 gram nanas terdapat kalori 52 Kal, protein 0,4 gram, lemak 0,2 gram, karbohidrat 13,7 gram, kalsium $16 \mathrm{mg}$, fosfor $11 \mathrm{mg}$, besi 0,3 mg, vitamin A $130 \mathrm{SI}$, vitamin B 0,08 mg, vitamin C 24 mgram, dan air 85,3 gram (Departemen kesehatan RI, 2008).

Klasifikasi ilmiah atau taksonomi dari nanas adalah sebagai berikut: Tanaman nenas dalam sistematika diklasifikasikan sebagai berikut: Kingdom: Plantae, Divisi: Spermatophyta, Class: Angiospermae, Family: Bromoliaceae, Genus: Ananas, Species: Ananas comosus L. Merr. Menurut Santoso (2010) berdasarkan bentuk daun dan buah dikenal 4 jenis golongan nanas yaitu 1) Cayenne memiliki ciri berdaun halus, ada yang berduri dan ada yang tidak berduri, ukuran buah besar, silindris, mata buah agak datar, berwarna hijau kekuningkuningan, dan rasanya agak masam, 2) Queen memiliki ciri berdaun pendek dan berduri tajam, buah berbentuk lonjong mirip kerucut sampai silindris, mata buah menonjol, berwarna kuning kemerah-merahan dan rasanya manis, 3) Spanish memiliki ciri berdaun panjang kecil, berduri halus sampai kasar, buah bulat dengan mata datar, 4) Abacaxi memiliki ciri berdaun panjang berduri kasar, buah silindris atau seperti piramida. Varietas nanas yang banyak ditanam di Indonesia adalah golongan Cayyene dan Queen. Golongan Spanish dikembangkan di Kepulauan India Barat, Puerto Riko, Meksiko dan Malaysia. Golongan Abacaxi banyak ditanam di Brazilia. Nanas (Ananas comosus. L) merupakan salah satu buah tropis yang memiliki nilai ekonomi yang cukup tinggi. Buah nanas selain digemari 
masyarakat untuk konsumsi buah segar, juga merupakan bahan baku industri buah kalengan dan olahan seperti selai, sirup dan lain-lain. Indonesia memiliki berbagai macam jenis nanas yang telah dibudidayakan oleh para petani mulai dari Sumatra sampai Irian Jaya. Nanas dapat tumbuh di wilayah dengan tipe iklim pertumbuhan yang berbeda-beda mulai dari dataran tinggi sampai dataran rendah.

Berdasarkan hasil wawancara dengan salah satu petani yang memiliki kebun nanas di desa madu sari kecamatan sungai raya, Kabupaten Kubu Raya. Jenis nanas yang ditanam yaitu nanas lokal atau nanas queen, karena nanas jenis ini yaitu memiliki persediaan bibit sangat banyak, mudah didapat dan perawatannya cukup mudah. Dalam sekali panen dengan luas kebun sebesar 3 Hektare menghasilkan \pm 2000 - 3000 buah nanas, pada saat panen raya bisa mencapai 7000 buah. Nanas yang dapat dipanen adalah nanas yang sudah berwarna kekuningan sepanjang $5 \mathrm{~cm}$ dimulai dari pangkal buah nanas. Petani biasanya menjual buah segar langsung kepada pembeli. Pada saat panen raya dimana harga jual rendah petani mengalami kerugian karena cepatnya buah nanas matang. Nanas hanya dapat bertahan dalam waktu satu minggu pasca panen, sehingga harus dijual dengan harga murah. Harga satuan buah nanas bervariasi tergantung dari kualitas buah nanas dimulai dari Rp 2.500 hingga Rp 7.000. Pengolahan buah nenas oleh ibu PKK di desa Madu sari selama ini dengan diolah menjadi selai, dan dodol dan masih dalam produksi untuk memenuhi kebutuhan pangan rumah tangga.

Untuk mencegah terjadinya kerugian karena membusuknya buah nanas, oleh sebab itu diperlukan inovasi untuk petani Kalimantan Barat dapat memanfaatkan keberlimpahan buah nanas ini. Oleh sebab itu perlu dicari alternative tambahan produk olahan nanas yang bernilai ekonomi untuk menambah penghasilan petani nanas. Teknologi pengolahan yang diintroduksikan dapat dilakukan sederhana dan mudah diterapkan serta digunakan petani.Masyarakat sasaran yaitu ibu ibu PKK di desa madu sari, yang berjumlah sekitar 15- 20 Orang. Kelompok ibu ibu PKK ini merupakan sebagian besar isteri petani nenas yang berada di RT/RW: 002/001, desa Madu Sari, kecamatan Sungai Raya, kabupaten Kubu raya. Dari sisi ekonomi para isteri petani nanas sudah pernah mencoba membantu ekonomi keluarga dengan mengolah produk nanas. namun saat ini sudah tidak dilakukan lagi karena 
terkendala kurangnya pengetahuan dan keterampilan jenis pengolahan alternative lainnya dalam bentuk pangan. Kurangnya pengetahuan dan keterampilan dalam pengemasan produk sehingga kurang memiliki daya tarik produk yang pernah di pasarkan. Melimpahnya buah nanas pada saat panen raya menyebabkan harga jual nanas rendah, selain itu umur simpan nanas pasca panen sangat singkat sehingga cepat membusuk. Untuk menambah penghasilan petani dan keluarga perlu alternatif pengolahan hasil panen nanas menjadi produk olahan yang beragam yang memilki nilai ekonomi. Dengan mengolahnya menjadi berbagai macam produk olahan maka akan meningkatkan daya simpan.

Pemanfaatan pangan lokal secara masif dinilai mampu memberikan kontribusi positif untuk memperkuat kedaulatan pangan nasional (http://bkp.pertanian.go.id). Program peningkatan diversifikasi dan ketahanan pangan masyarakat oleh badan ketahanan pangan tahun anggaran 2013 terdiri dari pedoman gerakan percepatan penganekaragaman konsumsi pangan, sebagaimana yang tertulis dalam Peraturan Menteri Pertanian15/Permentan/OT.140/2/2013Pasal $1 \mathrm{Bab}$ 1. Gerakan diversifikasi pangan semakin efektif apabila didukung oleh ketersediaan aneka ragam bahan pangan melalui pengembangan usaha pangan lokal dan perilaku konsumen dalam mengonsumsi aneka ragam pangan (Keputusan Menteri Pertanian Republik Indonesia No 64.1/KPTS/RC.110/J/12/2017).

\section{METODE}

Mitra dalam kegiatan PKM ini yaitu ibu PKK desa Madu Sari berjumlah 25 orang. Pengumpulan data menggunakan angket untuk mengukur respon ibu PKK setelah mengikuti pelatihan pelatihan pengolahan pangan lokal berbahan baku nanas (ananas comosus). Prosedur dimulai dengan kegiatan pelatihan dan pembimbingan meliputi persiapan alat dan bahan, menyapaikan materi tentang pentingnya pengolahan pasca panen, mnfaat nanas bagi kesehatan, prosedur mengurus ijin PIRT, pengemasan produk selanjutnya mendemonstrasikan langkahlangkah pengolahan pembuatan produk pangan berbahan baku nanas yaitu bisccoti nanas, jelly nanas, dan brownies nanas. Setelah dilakukan demonstrasi maka 
dilakukan pembuatan produk bersama dengan ibu PKK dibimbing oleh tim pengabdian. Diakhir kegiatan ibu PKK mengisi angket untuk mengetahui respon ibu PKK terhadap kegiatan pelatihan dengan memberi tanda checklist pada 10 pernyataan. Setelah angket diisi penilaian dilakukan dengan menggunakan skala Likert (Riduwan, 2011: 38). Langkah-langkah untuk menganalisis angket meliputi 1) Memeriksa dan menghitung skor pada angket dari setiap jawaban yang dipilih oleh responden 2) Merekapitulasi skor yang diperoleh, 3) Menghitung interpretasi skor tiap item 4) Menentukan kriteria intrepretasi skor yang ditunjukkan dari angket, 5) kriteria ditentukan sesuai modifikasi Riduwan (2011: 41) dengan intrepretasi skor sebagai berikut:

Tabel 1. Interpretasi Skor

\begin{tabular}{ll}
\hline Persentase & \multicolumn{1}{c}{ Interpretasi } \\
\hline $0 \%-20 \%$ & Sangat kurang \\
\hline $21 \%-40 \%$ & Kurang \\
\hline $41 \%-60 \%$ & Cukup \\
\hline $61 \%-80 \%$ & Tinggi \\
\hline $81 \%-100 \%$ & Sangat tinggi \\
\hline
\end{tabular}

\section{HASIL DAN PEMBAHASAN}

Respon ibu PKK desa Madu sari terhadap pelatihan disajikan pada Gambar 1. 


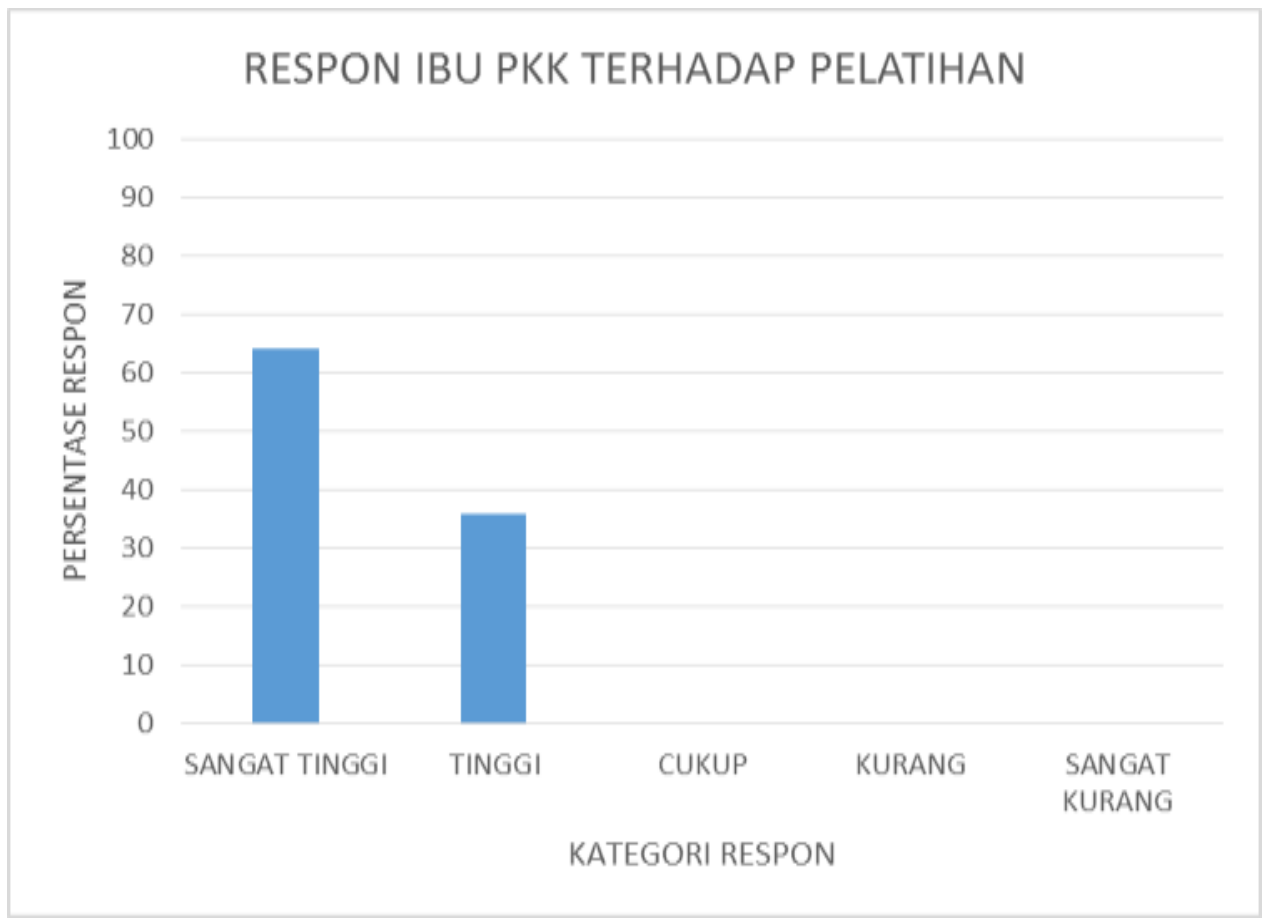

Gambar 1. Persentase respon ibu PKK terhadap pelatihan pengolahan pangan lokal berbahan baku nanas

Berdasarkan respon ibu PKK (Gambar 1) menunjukkan persentase respon sangat tinggi dan tinggi terhadap kegiatan pelatihan. Pengolahan dan pengemasan produk olahan nenas dilakukan secara langsung melalui kegiatan pelatihan dan praktek pembuatan olahan nenas menuntut keaktifanibu PKK. Mitra sangat antusias mengikuti pelatihan dan termotivasi untuk membuat kembali produk di rumah. Diakhir kegiatan peserta pelatihan telah mampu menghasilkan beragam olahan pangan dari nenas yaitu bisccoti nanas, jelly nanas dan brownies nanas.
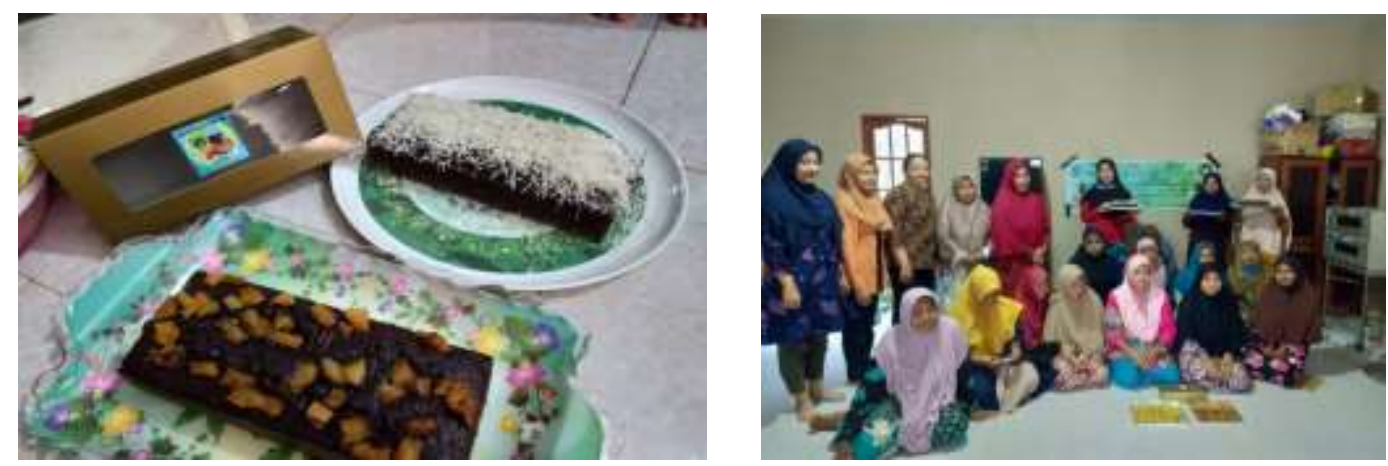

Gambar 2.(a) Brownies nanas sebagai salah satu produk olahan nanas, (b) Tim pengabdian dan ibu PKK menunjukkan hasil produk olahan nanas 
Permen Jelly tergolong dalam semi basah, oleh karena itu produk ini cepat rusak bila tidak dikemas secara baik. Permen dibuat tidak menggunakan bahan pengawet permen dibuat dengan proses penjemuran hingga permen kering. Permen sebagai inovasi pemanfaatan buah nanas karena banyak digemari oleh masyakat karena rasanya yang manis dan warnanya yang menarik. Permen jelly nanas terbuat dari sari buah nanas dan bahan pembentuk gel (agar-agar dan nutrijel) sehingga berpotensi untuk dipasarkan. Sensasi kenyal yang ditargetkan pada hasil olahan permen jelly sangatlah baik, hal ini dibuktikan dengan tekstur yang dihasilkan lentur, warna yang menarik dan tidak mengalami sineresis. Kesukaan konsumen terhadap permen jelly karena rasa yang ditimbulkan sangat baik (Herdiansyah, \& Ichsan, 2018).

Brownies merupakan kue basah yang modern berasal dari Eropa yang terkenal enak dan terbuat dari coklat yang sangat legit. Brownies memiliki kalori yang sangat tinggi karena menggunakan coklat dan terigu dengan komposisi cukup tinggi. Makanan ini digemari karena memiliki rasa yang enak dan dapat diterima dengan baik di Indonesia (Estiasih, 2015). Brownies sangat populer di kota-kota besar dengan minat daya beli yang cukup tinggi. Hal ini terbukti dengan banyaknya penjualan dan toko kue brownies sekarang ini. Bahan tambahan buah nanas yang telah diolah menjadi selai dan manisan nenas dijadikan sebagai bahan tambahan pada pembuatan produk brownies memberikan varian rasa dan sensasi pada tektur brownies. Produk ketiga yang dibuat yaitu biscotti nanas. Biscotti adalah biskuit garing khas Italia. Biscotti berbahan nanas ini sebagai alternatif pengganti bahan campuran biscotti seperti almond yang harganya cukup mahal.

Produk olahan nenas yang dihasilkan dapat dijadikan sebagai hidangan sehat baik pada hari raya ataupun cemilan untuk setiap hari. Selain itu produk olahan yang dilatihkan merupakan produk pangan yang memiliki nilai jual. Hal ini juga didukung dengan pelatihan pengemasan yang baik dan menarik, yang akan berkontribusi pada daya simpan produk tersebut. Terdapat tiga alasan utama untuk melakukan pembungkusan, yaitu sebagai syarat keamanan dan kemanfaatan, dapat melaksanakan program pemasaran, untuk meningkatkan laba perusahaan. Oleh karena itu perusahaan harus membuat kemasan semenarik mungkin. Dengan 
kemasan yang sangat menarik diharapkan dapat memikat dan menarik perhatian konsumen (Cenadi, 2000).

Tabel 2. Persentase ketercapaian tiap item angket

\begin{tabular}{llcc}
\hline No & \multicolumn{1}{c}{ Item pernyataan } & $\begin{array}{c}\text { Persentase } \\
\text { ketercapaian }\end{array}$ & Kategori \\
\hline 1 & $\begin{array}{l}\text { Pelatihan ini menambah wawasan saya } \\
\text { untuk mengolah nanas menjadi produk } \\
\text { pangan }\end{array}$ & 86 & $\begin{array}{l}\text { Sangat } \\
\text { Tinggi }\end{array}$ \\
\hline 2. & Penyampaian materi pelatihan sangat jelas & 84 & $\begin{array}{l}\text { Sangat } \\
\text { Tinggi }\end{array}$ \\
\hline 3 & $\begin{array}{l}\text { Setelah kegiatan pelatihan ini saya akan } \\
\text { mencobanya kembali di rumah }\end{array}$ & 85 & $\begin{array}{l}\text { Sangat } \\
\text { Tinggi }\end{array}$ \\
\hline 4 & $\begin{array}{l}\text { Setelah kegiatan ini saya akan mencoba } \\
\text { mengembangkan produk yang telah dibuat }\end{array}$ & 83 & Sangat \\
\hline 5 & $\begin{array}{l}\text { Setelah mengikuti pelatihan ini, saya } \\
\text { terampil mengolah nanas menjadi olahan } \\
\text { makanan yang sehat, bersih dan bernilai } \\
\text { ekonomis. }\end{array}$ & 84 & $\begin{array}{l}\text { Sangat } \\
\text { Tinggi }\end{array}$ \\
\hline 6 & $\begin{array}{l}\text { Saya sebelumnya belum mengetahui } \\
\text { olahan nanas dapat dibuat menjadi biscotti, } \\
\text { brownies, dan jelly nenas }\end{array}$ & 84 & Sangat \\
\hline 7 & $\begin{array}{l}\text { Saya yakin bisa membuat olahan nanas } \\
\text { menjadi olahan makanan seperti yang } \\
\text { telah diajarkan dalam pelatihan hari ini }\end{array}$ & 88 & Sangat \\
\hline 8 & $\begin{array}{l}\text { Materi pelatihan yang disampaikan bukan } \\
\text { hal baru bagi saya }\end{array}$ & 60 & Tinggi \\
\hline 9 & $\begin{array}{l}\text { Pelatihan yang disampaikan tidak } \\
\text { bermanfaat bagi saya }\end{array}$ & 77 & Tinggi \\
\hline 10 & $\begin{array}{l}\text { Saya sangat tertarik mengikuti pelatihan } \\
\text { ini }\end{array}$ & 91 & Tinggi \\
\hline
\end{tabular}

Berdasarkan angket yang diisi peserta $91 \%$ peserta tertarik mengikuti pelatihan ini. Peserta menyatakan sangat setuju pelatihan pembuatan olahan nenas menambah wawasan dan keterampilan sebesar $86 \%$. Selain itu setelah pelatihan peserta memiliki keinginan untuk mengembangkan dan mencobanya kembali di rumah masing-masing sebesar $83 \%$ dan $85 \%$. Hal ini karena dalam pelatihan juga disampaikan langkah langkah mudah membuat produk olahan dengan bantuan leaflet berisi resep yang disediakan oleh tim. Selain itu peserta juga memberikan respon terhadap terampil mengolah nanas menjadi olahan makanan yang sehat, 
bersih dan bernilai ekonomis sebesar 84\%. Pelatihan yang disampaikan juga memberikan informasi kandungan gizi dari nanas dan produk yang dibuat. Pemanfaatan nanas yang banyak mengandung vitamin, mineral dan zat gizi lainnya dapat menjadi alternatif pangan yang dapat dikonsumsi setiap hari untuk mencukupi asupan gizi harian dengan mengolahnya atau tanpa pengolahan terlebih dahulu.

\section{SIMPULAN}

Berdasarkan hasil analisis data diperoleh respon ibu PKK desa Madu Sari terhadap kegiatan pelatihan dengan kategori sangat tinggi sebesar 64\%, sedangkan kategori tinggi sebesar 36\%. Ketertarikan ibu ibu PKK dalam mengikuti pelatihan sebesar 91\%, sedangkan pelatihan menambah wawasan ibu ibu PKK sebesar $86 \%$. Dengan demikian dapat disimpulkan pelatihan pengolahan pangan lokal berbahan baku nanas memperoleh respon positif memberikan pengetahuan dan keterampilan ibu PKK desa Madu Sari Kabupaten Kuburaya.

\section{UCAPAN TERIMA KASIH}

Ucapan terimakasih kepada Fakultas Keguruan dan Ilmu Pendidikan Universitas Tanjungpura yang sudah mendukung kegiatan pelatihan dalam rangka kegiatan PKM melalui dana PNBP tahun 2019. Selain itu ucapan terimakasih kepada mitra ibu PKK desa Madu sari Kabupaten Kuburaya atas kerjasamanya yang baik.

\section{DAFTAR PUSTAKA}

Badan Pusat Statistik kabupaten Kubu Raya. (2017). Statistik pertanian tanaman hortikultura kuburaya tahun 2017. Kuburaya: BPS Kabupaten Kubu Raya

Badan Pusat Statistik Kalimantan Barat. (2017). Statistik pertanian tanaman sayuran dan buah-buahan Provinsi kalimantan barat Tahun 2017. Pontianak: Badan Pusat Statistik.

Badan Ketahanan Pangan. (2019). Percepatan diversifikasi pangan lokal untuk mendukung kedaulatan pangan nasional, (Online), (http://bkp.pertanian.go.id/blog/post/percepatan-diversifikasi-pangan-lokaluntuk-mendukung-kedaulatan-pangan-nasional, diakses 9 September 2019).

Cenadi, C. S. (2000). Peranan desain kemasan dalam dunia pemasaran. Nirmana, 
2(2),

92-103.

(Online), (http://puslit2.petra.ac.id/ejournal/index.php/dkv/article/view/16056).

Estiasih, T. (2015). Performance improvement and production capacity of brownte (eggplant brownies) healty food through technology transfer to the concept of" open kitchen" and" franchise" as a special food product of batu city. Journal of Innovation and Applied Technology, 1(1), 44-52.

Herdiansyah, D., \& Ichsan, I. (2018). PKM bagi Kelompok tani nanas dan kelompok pkk desa pematang tujuh kecamatan Rasau Jaya Kabupaten Kubu Raya Kalimantan Barat. Teknologi pangan: Media Informasi dan Komunikasi Ilmiah Teknologi Pertanian, 9(2), 187-190

Keputusan Menteri Pertanian Republik Indonesia no.64.1/KPTS/RC.110/J/12/2017 Tentang Petunjuk Teknis Pengembangan Pangan Pokok Lokal Tahun 2018

Peraturan Menteri Pertanian No.15/Permentan/OT.140/2/2013 Tentang Program Peningkatan Diversifikasi dan Ketahanan Pangan Masyarakat.

Prahasta, A. (2009). Agribisnis nanas. Bandung: Pustaka Grafika.

Riduwan. (2011). Skala pengukuran variabel variabel penelitian. Bandung: Alfabeta.

Santoso, I. H. B. (2010). Teknologi tepat guna manisan nanas. Yogyakarta: Kanisius. 